\title{
Gating Analysis on Woodball: in Terms of Biomechanics
}

\author{
Fajar Awang Irawan ${ }^{1, *}$ Bayu Setyo Utomo ${ }^{1,}$ Muchamad Arif Al Ardha ${ }^{2}$
}

\author{
${ }^{1}$ Department of Sports Science, Universitas Negeri Semarang, Indonesia \\ ${ }^{2}$ Department of Physical Education, Universitas Negeri Surabaya, Indonesia \\ *Corresponding author. Email: fajarawang@mail.unnes.ac.id
}

\begin{abstract}
The purpose of this study was to analyze the gating motion of woodball athletes in terms of biomechanics. The method used in this study was descriptive quantitative with a total sample of 8 athletes participating in this study. This study has passed the Ethical Clearance of Universitas Negeri Semarang, and all athletes are pleased to participate in the research to completion by signing the informed consent form. Analysis data was obtained through video recording on the gating woodball movement and analyzed using Kinovea software version 0.8.27. The results found an average age of $21.00 \pm$ 1.07 years, with an average height of $164.63 \pm 9.50 \mathrm{~cm}$ and a weight of $56.50 \pm 9.04 \mathrm{~kg}$. Kinematic data for gating woodball with a gating speed of $0.48 \pm 0.07 \mathrm{~m} / \mathrm{s}$, with a time series of movements reaching $1.3 \pm 0.18$ seconds. The conclusion in this study stated that the gating motion analysis of woodball from the biomechanics aspect view in the Appropriate category. However, it is necessary to improve the speed of the stroke to be more effective and accurate about the gate. Future study is expected to add kinetic data and video recording in motion analysis through the sagittal and frontal sides.
\end{abstract}

Keywords: Motion analysis, Gating, Woodball.

\section{INTRODUCTION}

Woodball is a sport developing in Indonesia, especially on Java, Bali, Sumatra, and Kalimantan islands. Woodball was first discovered in 1990 by Mr. Kuang-Chu Young from Taiwan. While in Indonesia, woodball was first developed in 2006 [11][19]. Some of the basic techniques used in playing woodball were gating and long-range hitting. The gating stroke was used to complete the woodball game on each fairway. According to Iman et al. [13], it is essential for woodball athletes to master the basic gating technique well because it is the key to getting points. The gating area in woodball is a circular gate area with a diameter of 5 meters with the goal as the center with an outer line of 2 meters. The angle for gating is at an angle of $45^{\circ}, 90^{\circ}$, and $135^{\circ}$ with the gate as the center. Skills in gating did not require a lot of body movement. Aguiar \& Sultoni [1] stated that the direction of the hit does not require a long mallet swing and great power. In close strokes, it must control the swing to place the ball precisely and adequately with the ball passing through the gate.

Observations made by researchers at the Monthly Game University and the FIK UNNES Open Woodball Championship found that the gating strokes made by 6 out of 8 woodball athletes still deviated from the target.
These errors are influenced by foot distance that is too narrow, legs that are too bent, unstable shaking of the hands, and the athlete's habit when after hitting the ball, immediately pulls the mallet without following through. This habit causes mistakes in gating strokes.

Gating in woodball requires a high concentration, accuracy, and skill; therefore, this movement must be reviewed and analyzed as techniques and trends in woodball games from the biomechanics aspect [11][20]. There are four phases in the gating stroke motion series, including the preparation phase, the prefix phase, the execution phase, and the advanced motion phase. The motion to get good gating results must be correct and effective because it is related to improving performance and minimizing the risk of injury [15][16]. Biomechanical analysis in gating is used to solve problems and obstacles that occur during playing woodball; it can provide an evaluation to improve good movements and performance [18]. The purpose of this study was to analyze the gating motion of woodball athletes in terms of biomechanics.

\section{METHODS}

The method in this study was the descriptive quantitative using observation by Video Recording. 
Under Arikunto, [5] research data obtained through video recording on the gating woodball movement were then analyzed using Kinovea software version 0.8.27. The total sample in this study was 8 Male woodball athletes from Universitas Negeri Semarang. All of them were willing to participate in the survey to completion by signing the informed consent form. All samples have also carried out a swab test in a pandemic atmosphere and were declared hostile before data collection. This research has been said to have passed the Ethical Clearance (EC) [18] Universitas Negeri Semarang with number 061/KEPK/EC/2021. The sampling technique in this study was to use purposive sampling with the criteria of athletes who are members of the UNNES Woodball team, have practiced for at least one year, and have participated in at least Regional Championships.

The instrument in this study used video recordings (Camera Canon EOS M3) assisted by the Kinova Table 1. Personal Data of Woodball Athletes application [22] in analyzing kinematic data on the movement of the Gating stroke using an analyzer and slow-motion, which makes the video play slowly to check the activity and can be seen clearly and detail. The analysis procedure was to collect all video recordings and then input them into the analyzer to find out and analyze the kinematic data. The data was then analyzed so that the athlete's mistakes for shortcomings or weaknesses could be identified when performing a series of gating strokes. Movement analysis focused on the preparation, prefix, execution, and follow-through, including the body segment's time, speed, and angle.

\section{RESULTS}

The results found an average age of $21.00 \pm 1.07$ years, with an average height of $164.63 \pm 9.50 \mathrm{~cm}$ and a weight of $56.50 \pm 9.04 \mathrm{~kg}$, which can be seen in table 1 .

\begin{tabular}{|l|l|l|l|}
\hline$n=8$ & Mean \pm SD & Min & Max \\
\hline Height $(\mathrm{cm})$ & $164.63 \pm 9.50$ & 158 & 178 \\
\hline Weight $(\mathrm{kg})$ & $56.50 \pm 9.04$ & 48 & 73 \\
\hline Arm Length $(\mathrm{cm})$ & $68.13 \pm 5.51$ & 61 & 75 \\
\hline Leg Length $(\mathrm{cm})$ & $96.38 \pm 6.25$ & 84 & 103 \\
\hline Age (year) & $21.00 \pm 1.07$ & 20 & 23 \\
\hline
\end{tabular}

In this study, kinematic data is showed to present information related to data on speed, time, mallet height and distance, leg width, and angles at the elbows and knees in the preparation, prefix, execution, and followthrough (table 2)

Table 2. Kinematic Data on Woodball Gating

\begin{tabular}{|c|c|c|c|}
\hline$n=8$ & Mean \pm SD & Min & Max \\
\hline Speed (m/s) & $0.48 \pm 0.07$ & 0.33 & 0.54 \\
\hline Time (s) & $1.30 \pm 0.18$ & 1.13 & 1.60 \\
\hline \multicolumn{4}{|l|}{ Preparation Phase } \\
\hline Mallet High (m) & - & - & - \\
\hline Mallet Distance (m) & - & - & - \\
\hline Time (s) & - & - & - \\
\hline Foot Width (m) & $0.18 \pm 0.05$ & 0.10 & 0.26 \\
\hline Knee Flexion Angle (0) & $165 \pm 4.87$ & 158 & 172 \\
\hline Right Elbow Flexion Angle (0) & $177 \pm 5.19$ & 170 & 185 \\
\hline Left Elbow Flexion Angle (0) & $182 \pm 9.78$ & 170 & 196 \\
\hline \multicolumn{4}{|l|}{ Prefix Phase } \\
\hline Mallet High (m) & $0.19 \pm 0.07$ & 0.11 & 0.33 \\
\hline Shoulder High (m) & $0.91 \pm 0.04$ & 0.84 & 0.98 \\
\hline Mallet Distance (m) & $0.62 \pm 0.08$ & 0.52 & 0.75 \\
\hline Time (s) & $0.99 \pm 0.16$ & 0.86 & 1.13 \\
\hline Right Elbow Flexion Angle (0) & $170 \pm 4.69$ & 162 & 176 \\
\hline Left Elbow Flexion Angle (0) & $185 \pm 114$ & 168 & 206 \\
\hline
\end{tabular}




\begin{tabular}{|l|l|l|l|l|}
\hline \multicolumn{2}{|l|}{ Execution Phase } & & & \\
\hline & Mallet High (m) & - & - & - \\
\hline & Shoulder High (m) & $0.90 \pm 0.04$ & 0.83 & 0.98 \\
\hline & Mallet Distance (m) & - & - & - \\
\hline & Time (s) & $0.32 \pm 0.05$ & 0.23 & 0.4 \\
\hline & Right Elbow Flexion Angle (0) & $179 \pm 6.35$ & 171 & 189 \\
\hline & Left Elbow Flexion Angle (0) & $188 \pm 5.22$ & 182 & 197 \\
\hline Follow Through & & & \\
\hline & Mallet High (m) & $0.41 \pm 0.10$ & 0.24 & 0.56 \\
\hline & Shoulder High (m) & $0.99 \pm 0.05$ & 0.90 & 1.07 \\
\hline & Mallet Distance (m) & $0.71 \pm 0.11$ & 0.48 & 0.85 \\
\hline & Time (s) & $0.45 \pm 0.06$ & 0.4 & 0.53 \\
\hline & Right Elbow Flexion Angle (0) & $181 \pm 5.92$ & 171 & 190 \\
\hline & Left Elbow Flexion Angle (0) & $181 \pm 9.26$ & 170 & 192 \\
\hline
\end{tabular}

Table 2 presents the kinematic data of the woodball gating, which was the average gating speed was $0.48 \pm$ $0.07 \mathrm{~m} / \mathrm{s}$, with the time in one series of movements reaching $1.3 \pm 0.18$ seconds. The gating stroke in woodball, which was carried out in the preparatory phase, obtained data for a leg width of $0.18 \pm 0.05$ meters, with a knee flexion angle of $165 \pm 0.05$ degrees, a right elbow flexion angle of $177 \pm 5.19$ degrees, and a left elbow flexion angle of $182 \pm 9.78$ degrees.

\section{DISCUSSION}

This study analyzed the gating motion of the woodball by referring to the previous research by Dewi [9][10]. This study is divided into the preparation phase, the initial phase, the implementation phase, and the advanced mobile phase. The analysis in this study is helpful to determine the suitability of the gating movement carried out as an evaluation guide for coaches and athletes themselves. The assessment of the suitability of the gating stroke was taken from research by Dewi [9] and analyzed using the Kinovea motion analysis application program.

Arm length and leg length of woodball athletes can have an influence on the stroke in this study where the size of the arms and legs reduces the athlete's center of gravity (COG) when hitting the ball that will affect balance and accuracy [2][4] when hitting the ball.

The analysis in this study showed that the average time required to perform backswing gating strokes for woodball athletes was 1.30 seconds, and the average gating speed was 0.48 meters per second. The results of the data from the time and speed in this study were compared with the previous survey by Dewi \& Broto, [8] and Dewi, [10] in which the average time required to hit was 2.14 seconds with an average speed of 0.54 meters/second. Notes in previous studies Dewi, [9][10] was that athletes hit strokes carefully and require more prolonged concentration to get optimal results. The achievement of the time with the gating speed of the woodball athletes in this study is quite effective. This is reinforced by the three hits made by the athletes during the study, and the average ball that goes into the gate was 1.63 times.

Based on a previous study that Amin et al., [3] referred to the references related to golf strokes. This indeed has the same movement and some kinematic data. Although the numbers are different, the results are significantly the same. This study's data on foot distance is between 0.10 meters to 0.26 meters, while the mallet distance is 0.52 meters to 0.75 meters. The time required for this gating stroke is 1.13 seconds to 1.60 seconds, for the required speed of 0.46 meters per second to 0.56 meters per second. Compared with a previous study by Iragraha et al. [14], the time required to perform a backswing is 2.14 seconds, with an average speed of 0.54 meters/second. The knee flexion angle is 19 degrees, and the left elbow angle is 22 degrees.

Based on the previous studies ([6][13][14] as a reference, the woodball athlete's gating stroke at Universitas Negeri Semarang is in the reasonably Efficient category. Woodball athletes sometimes do not pay attention to the ideal foot distance, shoulder-width [20]. Then the influential knee position must be bent to a mallet height that allows the athlete to get an accurate image that leads to the gate. There needs to be coordination in making strokes among the arms, hands, and gaze at the target. In line with this, Dewi [10] stated that good coordination and balance are needed to perform basic woodball stroke techniques to master the movement correctly and adequately. This is reinforced by Imaduddin, [12] which is arm muscle strength, back muscle strength, and trunk length significantly affect the results of the blows made during a match. Improving the correctness of motion [26] is expected to increase the 
effectiveness and efficiency of gating strokes in making strokes while competing.

The gating motion phase on woodball is presented in Figure 1 that simulating a series of strokes consisting of 4 phases according to Kriswantoro [19] study, including 1) the preparation phase, 2) the prefix phase, 3) the execution phase, and 4) follow-through
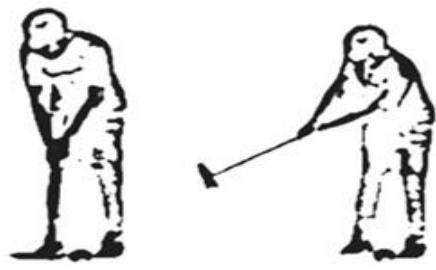

(1) Preparation Phase

(3) Execution Phase

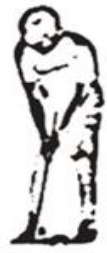

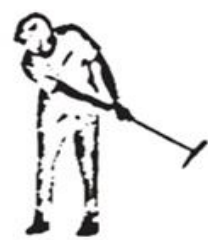

(4) Follow Through
(2) Prefix Phase

Figure 1. Gating Movement Phase

The preparatory phase starts from the initial position holding the mallet to the position backswing movement. The initial phase continues the preparation phase by swinging the mallet backward or backswing until the mallet is swung forward. The implementation phase continues the motion from the prefix phase until the mallet hits the ball. The advanced phase is the last phase where the mallet movement after hitting the ball does not just stop, but the arm continues the training by holding the mallet by swinging it forward as a follow-up to the woodball stroke (figure 1).

In contrast to Dewi, [9] divided the gating stroke phase into 3 phases, there were: 1) the preparation phase, 2 ) the execution phase, and 3 ) the follow-through phase. The preparation phase starts when holding the mallet until it does a downswing. The execution phase begins after doing the backswing until the mallet hits the ball or called impact. The follow-through phase after impact until the mallet swings forward and down again. This four-stage phase was more appropriate for this study. Indirectly, the stroke phase using four or three phases is not much different, but the stages using 4 phases provide a more detailed description and understanding of the analysis and evaluation. It will be more effectively used in the application in the field. Indicators in determining the suitability of motion and kinematic data are also easier to analyze using Kinovea.

Learning to strike accurately can be a foundation for lifelong physical activities and sports [7]. Chang \& Lee [7] also stated that Woodball could be used as a content sport in physical education and physical activity to help people acquire a vertical pattern in striking to use the learned skills in other sports. The motion analysis related to the effectiveness of the use of gating. Hence, it is concluded that the tool such as mallet should be suitable for use as a gating drill too [25]. A significant finding by Sumariyanto et al. [24] that underlies the formation of the wood swing tool is suggested that the wood swing tool can help the achievements of woodball athletes at the world level.

The practical woodball kid's model has been produced to introduce woodball sports in physical education learning in elementary school [23]. The critical finding that underlies the creation of this woodball kid's tool is the development of a woodball game model combined with physical education. The woodball kids game model in the learning process uses media such as the woodball kids tool developed in this study. The development of equipment and techniques in woodball is expected to support increasing the ability to hit woodball, especially gating. This application can be used to improve performance in improving gating accuracy or standards in gating strokes on woodball.

Gating on woodball is a stroke that is a mainstay for athletes. This stroke is to get points in determining the victory and reduce the occurrence of injuries during the movement. The coordination between the athlete and the mallet is also the most essential part, where the athlete must be able to control the mallet to maximize the strokes made. When looking at the contact area between the ball and mallet head, the collision zone was relatively small though the contact pressure was reached up. The maximal stress was concentrated in the proximal mallet fracture that happened in an actual performing event [21].

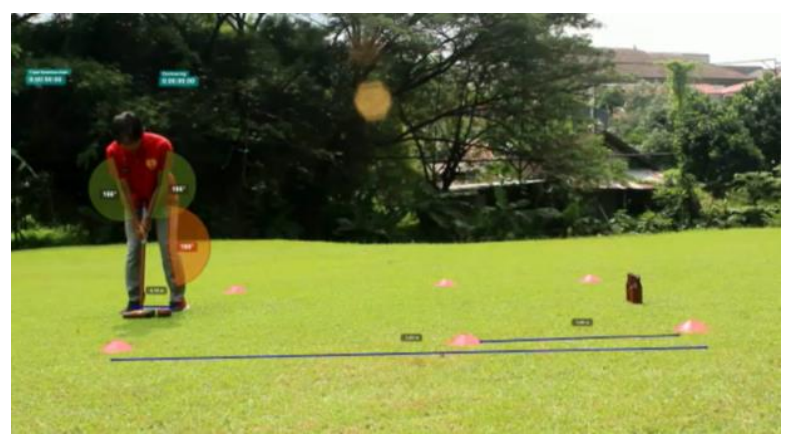

Figure 2. Gating in Frontal Plane

Figure 2 describes the gating stroke seen from the frontal plane. This stroke series consists of four phases where composure, concentration, and coordination are needed when hitting the ball towards the gate.

In this study, there are several limitations, including the number of samples participating in the study. There 
are still related social distancing in the pandemic covid 19 , and the data in this study only focuses on kinematic data.

\section{CONCLUSION}

The conclusion in this study showed that the gating motion analysis of woodball athletes is viewed from the biomechanics aspect in the appropriate category. The correct movement under basic technical guidelines can increase the effectiveness and efficiency of gating strokes, especially to get points. However, it is necessary to improve the speed of the stroke to make it more effective under the kinematic research data. Future research is expected to add kinetic data and video recording in motion analysis through the sagittal and frontal sides.

\section{ACKNOWLEDGMENTS}

The author would like to thank the Department of Sports Science, Faculty of Sports Science, Universitas Negeri Semarang for the research permission and the UNNES Woodball Team's willingness to participate in this research.

\section{REFERENCES}

[1] Agustiar, O., \& Sultoni, K. (2016). Hubungan Tingkat Kecemasan Dengan Hasil Pukulan Gate-in Pada Olahraga Woodball. Jurnal Terapan Ilmu Keolahragaan, 1(2), 64. https://doi.org/10.17509/jtikor.v1i2.4002

[2] Akhromawati, H. R. (2018). Tingkat Konsentrasi dan Koordinasi Mata Tangan Untuk Ketepatan Shooting Petanque. Universitas Negeri Semarang.

[3] Amin, A. K., Doewes, M., \& Purnama, S. K. (2017). Pengembangan Prototipe Alat Bantu Latihan Mengayun Pada Cabang Olahraga Woodball Di Jawa Tengah. Prosiding Seminar Nasional \& Internasional, 1(1), 30-38.

https://jurnal.unimus.ac.id/index.php/psn12012010/ article/view/2270

[4] Anam, K., Irawan, F. A., \& Nurrachmad, L. (2018). Pengaruh Metode Latihan dan Koordinasi MataKaki terhadap Ketepatan Tendangan Jarak Jauh. Jurnal Media Ilmu Keolahragaan Indonesia, 8(2), 57-62.

[5] Arikunto, S. (2013). Prosedur Penelitian Suatu Pendekatan Praktik. Rineka Cipta.

[6] Chandrasegaran, J., Azani Mustafa, W., Aminudin Jamlos, M., \& Zulkarnain Syed Idrus, S. (2020). Design Woodball Line Detection and Monitoring System: A Preliminary Study. IOP Conference Series: Materials Science and Engineering, 917(1), $1-13$. https://doi.org/10.1088/1757899X/917/1/012069

[7] Chang, S. H., \& Lee, J. (2017). Teaching Striking Skills in Elementary Physical Education Using
Woodball. Journal of Physical Education, Recreation \& Dance, VOl.88(No.8), pp.21-27. https://doi.org/10.1080/07303084.2017.1356767

[8] Dewi, I. S., \& Broto, D. P. (2019). Pengembangan Tes Keterampilan Pukulan Jarak Jauh Woodball Siswa Sekolah Dasar Kelas Atas. Jurnal Pendidikan Jasmani Indonesia, 15(2), 50-61.

[9] Dewi, P. C. P. (2015). Identifikasi Keterampilan Pukulan Olahraga Woodball. Jurnal Pendidikan Kesehatan Rekreasi, 2(1), 31-41.

[10]Dewi, P. C. P. (2016). Analisis Komponen Biomotorik Pada Olahraga Permainan Woodball Jurnal Pendidikan Olahraga Rekreasi, 1(1), 81-87.

[11]Dwiyogo, wasis D., \& Kriswantoro. (2009). Olahraga Woodball. In Olahraga Woodball (1st ed.). Wineka Media.

[12] Imaduddin, M. F. (2020). Hubungan Kekuatan Otot Lengan dan Koordinasi Mata Tangan Terhadap Penguasaan Teknik Pukulan Jarak Jauh (Long Stroke) Pada Cabang Olahraga Woodball. JPOS Journal Power of Sports, 3(2), 37-41.

[13]Iman, I. M. I., Rahayu, N. I., \& Sultoni, K. (2017). Pengaruh Imagery Training Terhadap Hasil Pukulan Parking dan Gate-in Woodball di UKM Woodball UPI. Jurnal Terapan Ilmu Keolahragaan, 2(2), 91. https://doi.org/10.17509/jtikor.v2i2.4414

[14]Iragraha, S. M. F., Soegiyanto, Setijono, H., \& Sugiharto. (2019). The Role of Woodball Sports Organization Universitas Negeri Semarang (Unnes) in Producing Talented Athletes. International Journal of Engineering and Advanced Technology, 9(2), 4928-4932. https://doi.org/10.35940/ijeat.b3308.129219

[15]Irawan, F. A., Chuang, L.-R., Peng, H.-T., \& Huang, S.-K. (2016). A Biomechanical Baseball Pitching: Is the curveball more risk than the fastball? Chinese Journal of Sport Biomechanics, vol.13(no.2), pp.5563. https://doi.org/10.3966/207332672016121302002

[16]Irawan, F. A., \& Long-Ren, C. (2015). Comprehensive Pitching Biomechanics and Injury Prevention for Young Baseball Pitchers-A review. Journal of Physical Education and Sport Science, $21,11-21$.

[17] Irawan, F. A., \& Marsiwati, C. D. (2019). Peralatan Woodball di Jawa Tengah. In D. F. W. Permana (Ed.), Buku Cetak. Fakultas Ilmu keolahragaan, Universitas Negeri Semarang.

[18] Irawan, F. A., Nurrahmad, L., \& Permana, D. F. W. (2020). The Association of Arch Height Index and Arcus Pedis on Agility: An Overview of Sport Science College Students. International Journal of Innovation, Creativity, and Change, 14(11), 669676.

https://doi.org/DOI: 10.53333/IJICC2013/141108 
[19] Kriswantoro. (2015). Teknik Dasar Bermain Woodball (M. O. Sri Haryono (ed.); 1st ed.). Fastindo.

[20] Kriswantoro, \& Lumbanraja, E. S. (2016). Pengaruh Jenis Pegangan Terhadap Hasil Akurasi Gating Pada Woodball. Journal of Sport Coaching and Physical Education, 1(1), 1-7.

https://journal.unnes.ac.id/sju/index.php/jscpe/articl e/view/23348

[21]Lu, Y., \& Luo, Y. (2014). Woodball mallet loading analysis during maximal swing stage: A finite element study. Journal of Chemical and Pharmaceutical Research, Vol.6(No.6), pp.756-759.

[22] Muhammad, H. N., Al Ardha, M. A., Priambodo, A., \& Wibowo, S. (2019). Woodball Shooting Technique Analysis in Biomechanic Perspective. Advances in Social Science, Education and Humanities Research, 362(ACPES), 69-72. https://doi.org/10.2991/acpes-19.2019.15

[23]Said, M. I., Rustiadi, T., \& Rahayu, S. (2018). The Development Model of Woodball Kids Tools for
Learning Physical Education in Elementary School. Journal of Physical Education and Sports, Vol.7(No.3), pp.220-224.

[24] Sumariyanto, A., Rahayu, T., \& Sulaiman. The Development of a Woodball Swing Tool Model for UNNESWoodball Students (Student Activity Units). (2018). Journal of Physical Education and Sports, Vol.7(No.3), pp.242-245.

[25]Wicaksono, W., Rahayu, T., \& Rumini, R. (2018). The Development of Gating Drill Tool of Woodball Sports Branch on Central Java Woodball Athlete. Journal of Physical Education and Sports, Vol.7(No.3), pp.246-249. https://journal.unnes.ac.id/sju/index.php/jpes/article /view/24892

[26] Yulianingsih, I., Parlindungan, D., \& Ghani, M. Al. (2020). Korelasi Kecerdasan Emosi Dengan Hasil Pukulan Gating Dalam Permainan Woodball Pada Atlet Junior Pamulang Woodball Club (PWBC). SMART SPORT Jurnal Olahraga Dan Prestasi, 17(1), 18-22. 